\title{
Bioremediation of Lindane by Wood-Decaying Fungi
}

\section{Biorazgradnja lindana pomoću gljiva uzročnika truljenja drva}

\author{
Original scientific paper • Izvorni znanstveni rad \\ Received-prispjelo: 8. 2. 2012. \\ Accepted-prihvaćeno: 15. 11. 2012. \\ UDK: $630 * 844.2$ \\ doi:10.5552/drind.2012.1226
}

\begin{abstract}
The object of this paper is to study the ability of four white-rot fungi (Trametes versicolor $\underline{\text { Hypoxylon }}$ fragiforme, Chondrostereum purpureum, and Pleurotus ostreatus) and one brown-rot fungus (Gloeophyllum trabeum) to degrade the organochlorine insecticide lindane in liquid cultures. The evaluation of lindane biodegradation was performed using two analytical procedures. In order to extract and properly quantify the remaining lindane from fungal liquid cultures, two different extraction procedures were used: extraction from filtrates and extraction from homogenized fungal cultures. White-rot fungi were able to degrade lindane. The amount of degraded lindane

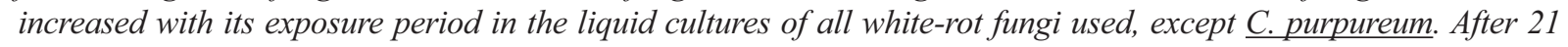
days of exposure, over $90 \%$ of lindane was degraded by $\underline{\text {. versicolor }} \underline{H}$. fragiforme, and $\underline{P}$. ostreatus. Degradation

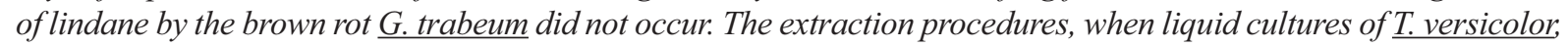
$\underline{H}$. fragiforme, and $\underline{P}$. ostreatus were used, had no noticeable effect on the determined degradation after 21 days of exposure. On the other hand, the amount of remaining lindane in liquid cultures of C. purpureum and $\underline{G}$. trabeum depended strongly on the extraction procedure. Our study indicates that mycoremediation studies of lindane should also consider adsorption onto mycelial biomass as a possible reason for the removal of the insecticide from the liquid medium, especially where shorter exposure periods are studied or fungi with poorer degradation potentials are used.
\end{abstract}

Keywords: biodegradation, lindane, white rot, adsorption, gas-chromatography

SAŽETAK • U radu se prikazuje istraživanje sposobnosti četiriju gljiva bijele truleži (Trametes versicolor, Hypoxylon fragiforme, Chondrostereum purpureum i Pleurotus ostreatus) te jedne gljive smeđe truleži (Gloeophyllum trabeum) za razgradnju organoklorova insekticida lindana u tekućim kulturama. Procjena biorazgradnje lindana izvedena je uz pomoću dvaju analitičkih postupaka. Kako bi se izdvojio i pravilno kvantificirao preostali lindan u tekućim kulturama gljiva, primijenjena su dva različita ekstrakcijska postupka: ekstrakcija iz filtrata $i$ ekstrakcija iz homogenizirane kulture gljiva. Dokazano je da su gljive bijele truleži razgradile lindan. Količina razgrađenog lindana povećava se s trajanjem izlaganja u tekućim kulturama svih gljiva bijele truleži, osim gljive

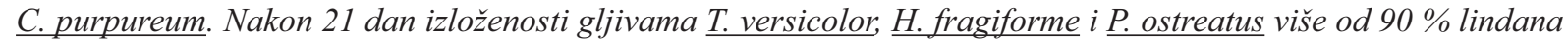
bilo je razgrađeno. Razgradnje lindana od gljive smeđe truleži G. trabeum nije bilo. Postupak ekstrakcije imao je

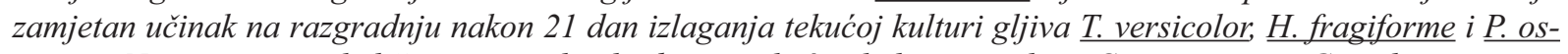

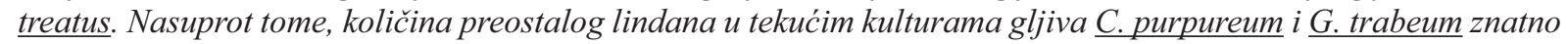
ovisi o postupku ekstrakcije. Ovaj rad pokazuje da bi se u istraživanju mikorazgradnje lindana trebala razmotriti i adsorpcija na micelije biomase kao mogući razlog za uklanjanje insekticida iz tekućeg medija, posebno kada se proučavaju kraća razdoblja izloženosti ili kada se koriste gljive s manjim potencijalom razgradnje.

Ključne riječi: biorazgradnja, lindan, bijela trulež, adsorpcija, plinska kromatografija

\footnotetext{
${ }^{1}$ Authors are assistant and professor at Biotechnical Faculty, University of Ljubljana, Ljubljana, Slovenia. ${ }^{2}$ Authors are professors at University of Ljubljana, Faculty of Chemistry and Chemical Technology, Ljubljana, Slovenia. ${ }^{3}$ Author is scientist at Institute of Wood Science and Technology and Sustainable Development, Ljubljana, Slovenia.

Autori su asistentica i profesor Bioethničkog fakulteta Sveučilišta u Ljubljani, Ljubljana, Slovenija. ${ }^{2}$ Autori su profesori Fakulteta kemije i kemijske tehnologije Sveučilišta u Ljubljani, Ljubljana, Slovenija. ${ }^{3}$ Autor je znanstvenik Instituta za znanost o drvu, drvnu tehnologiju i održivi razvoj, Ljubljana, Slovenija.
} 


\section{INTRODUCTION}

\section{UVOD}

Lindane (gamma isomer of 1,2,3,4,5,6-hexachlorocyclohexane, $\gamma-\mathrm{HCH}$ ) is a persistent chlorinated insecticide, which has been used worldwide mostly in agriculture for pest control as well as for human medicinal applications and wood protection. Besides its high persistence in the environment, lindane also bioaccumulates in fat tissue due to its high solubility in lipids, affecting non-target organisms, also including human beings (Lal and Saxena, 1982; Willet et al., 1998; Zucchini, 2009). Use of lindane is therefore prohibited in many countries and it was listed under the Stockholm Convention on Persistent Organic Pollutants in 2009 (UNEP, 2009).

Bioremediation using fungi (mycoremediation) is possible on a wide range of pollutants. In particular, white-rot fungi show the capability of degrading a variety of organopollutants. Degradation of such xenobiotics is thought to involve lignin-degrading system and its extracellular enzymes (laccases, lignin peroxidases and manganese peroxidases). The production of these enzymes is triggered by nutrient deficiency rather than by the presence of the pollutant (Bumpus et al., 1985; Kirk and Farrell, 1987). However, there have been reports on the production of ligninolytic enzymes even in nutrient sufficient media (Moreira et al., 1997; Janse et al., 1998).

Expression of ligninolytic genes in general is repressed by the presence of easily available nutrients (e.g. glucose) and induced in the presence of substrate polymers or their derivatives. Laccase genes are transcribed at low constitutive levels in many basidiomycetous fungi (Cullen, 1997; Aro et al., 2005). The expression can be enhanced using inducers such as aromatic compounds, including degradation products of lignin, which also induce expression of other ligninolytic genes (Muñoz et al., 1997; Scheel et al., 2000).

Several studies have been done concerning fungal degradation of lindane. Reported degradations of lindane with different white-rot fungi vary greatly, with maximum values ranging between over $90 \%$ and less than 5 $\%$ (Bumpus et al., 1985; Mougin et al., 1996; Singh and Kuhad, 1999; Quintero et al., 2008). The majority of the studies were performed using Phanerochaete chrysosporium, which was reported to be able to degrade a vast variety of organopollutants, including lindane (Bumpus et al., 1985; Mougin et al., 1996; Pointing, 2001). Mougin et al. (1996) and Singh and Kuhad (1999) also reported the identification of polar metabolites produced during fungal degradation of lindane.

In the present research, four white-rot fungi and one brown-rot fungus were exposed to lindane and its degradation dynamics was studied. Since the degradation results in previously published studies were rather diverse and possible adsorption onto mycelial biomass was not always taken into consideration in many of them, two different extraction procedures were used to quantify the remaining lindane in the liquid media in order to determine the actual degradation rates.

\section{MATERIALS AND METHODS}

2. MATERIJALI I METODE

\subsection{Chemicals and fungal cultures}

2.1. Kemikalije i kulture gljiva

All chemicals used in the experiment were p.a. grade. Stock solution of lindane was prepared in acetone. Final concentration of lindane in liquid fungal cultures was $30 \mu \mathrm{M}$.

Trametes versicolor (L.) Lloyd (ZIM L recently isolated strain), Pleurotus ostreatus (Jacq.) P. Kumm. (ZIM L recently isolated strain), Hypoxylon fragiforme (Pers.) J. Kickx (ZIM L108), Chondrostereum purpureum (Pers.) Pouzar (ZIM L007), and Gloeophyllum trabeum (Pers.) Murrill (ZIM L017) were obtained from the ZIM collection (Raspor et al., 1995) at the Biotechnical Faculty, Ljubljana and grown on potato dextrose agar (DIFCO Laboratories). For the study of lindane mycoremediation, liquid culture medium as described by Hadar and Cohen-Arazi (1986) was used.

Fungal cultures were grown in $50 \mathrm{~mL}$ of liquid medium, inoculated with three mycelial plugs $(9 \mathrm{~mm}$ in diameter), which were excised from seven-day-old agar cultures of respective fungi. The fungal liquid cultures were kept agitated $(100 \mathrm{rpm})$ on a shaker at $25^{\circ} \mathrm{C}$ in the dark for 26 days.

\subsection{Exposure of fungal liquid cultures to lindane} 2.2. Izlaganje tekućih kultura gljiva lindanu

Four days prior to lindane addition, veratryl alcohol, a fungal secondary metabolite, was added to fungal liquid cultures (final concentration $2 \mathrm{mM}$ ) in order to induce the production of ligninolytic enzymes (Faison and Kirk, 1985; Faison et al., 1986; Scheel et al., 2000). Fungal cultures were grown for 26 days and lindane was added 10 minutes, two hours, six hours, one day, three days, and 21 days prior to the end of the experiment. Uninoculated liquid media with addition of lindane (for $10 \mathrm{~min}$ and 21 days) and fungal liquid cultures without lindane were kept as controls. All experiments were carried out in triplicates.

\subsection{Remaining lindane extraction and GC analysis} of the extracts

2.3. Ekstrakcija preostalog lindana i GC analiza ekstrakta

Two different extraction procedures were performed for each set of samples, one from filtrates and the other from homogenates. In the first procedure, hexane $(1: 1, \mathrm{v} / \mathrm{v})$ was added to the fungal liquid culture and the content of the flask was shaken vigorously for three minutes. To remove mycelial biomass, the mixture was filtrated (Sartorius, Grade 388, $84 \mathrm{~g} \mathrm{~m}^{-2}$ ) using a water pump. When necessary, the filtrates were centrifuged (3 min, 4,000 rpm) to separate the aqueous phase from the organic phase, which was then further analyzed for remaining lindane.

In the other extraction procedure, the fungal liquid culture was removed from the Erlenmeyer flask and the flask was washed thoroughly with hexane (50 $\mathrm{mL}$ ), which was then added to the fungal culture. The obtained mixture was homogenized (T25 Digital UltraTurrax, 11,000 rpm, $30 \mathrm{~s}$ ) and then centrifuged (5 min, 
4,000 rpm). The upper, organic phase was removed and subjected to analysis.

Remaining lindane was quantified using gas chromatography (GC). GC analyses were performed by a Hewlett Packard 6890 Series chromatograph (Hewlett Packard) equipped with ECD detector and Restek RTX-5MS capillary column $(60 \mathrm{~m} \times 0.25 \mathrm{~mm} \times$ $0.5 \mu \mathrm{m})$. The injector and detector temperatures were $250{ }^{\circ} \mathrm{C}$ and $320{ }^{\circ} \mathrm{C}$, respectively. The initial column temperature was $70{ }^{\circ} \mathrm{C}$ for $1 \mathrm{~min}$, then increased linearly at $30{ }^{\circ} \mathrm{C} \mathrm{min}^{-1}$ to $300{ }^{\circ} \mathrm{C}$ and finally kept constant for $5 \mathrm{~min}$. The nitrogen carrier gas flow rate was set to

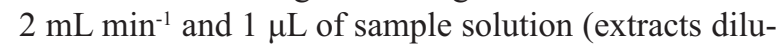
ted in hexane, 1:10) was injected each time. The retention time of lindane was 10.9 min.

\section{RESULTS}

3. REZULTATI

Fig. 1 presents an example of chromatograms. Lindane peak area was much larger when the control sample was analyzed, compared to the sample with $P$. ostreatus exposed to lindane, indicating efficient lindane degradation when fungus was used. In both cases the remaining lindane was extracted after 21 days in the medium.

Fungal degradation of lindane determined with different extraction procedures is presented in Fig. 2.

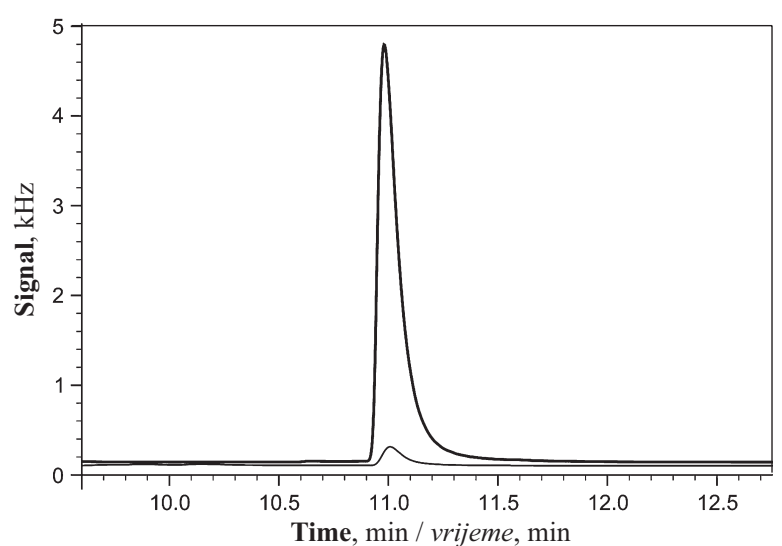

Figure 1 Chromatogram of control sample, represented with the thick line (liquid medium with lindane but without fungal culture), and exposed sample (remaining lindane extracted from homogenised liquid culture of $P$. ostreatus), represented with the thin line, both incubated for 21 days. The ECD detector used in the analyses mainly detects chlorinated compounds and therefore also lindane and its potential degradation metabolites.

Slika 1. Kromatogram kontrolnog uzorka prikazan zadebljanom linijom (tekući medij s lindanom, ali bez kulture gljiva) i izloženi uzorak (preostali lindan ekstrahiran iz homogenizirane tekuće kulture gljive $P$. ostreatus), prikazan tankom linijom, nakon razdoblja od 21 dan. $\mathrm{Uz}$ pomoć ECD detektora u analizama uglavnom su otkriveni klorirani spojevi, dakle i linden, te potencijal za razgradnju njegovih metabolita.
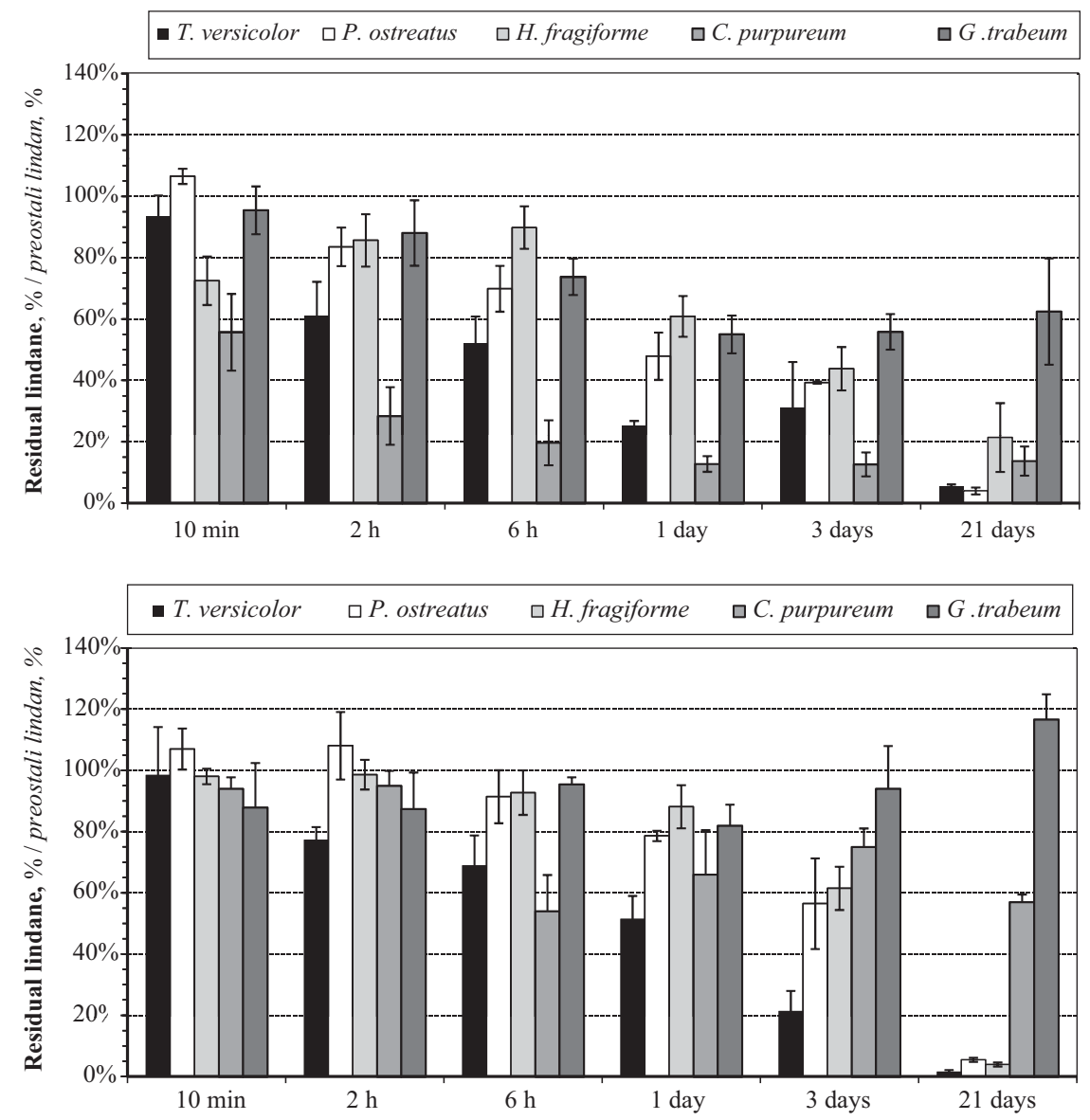

Figure 2 Fungal degradation of lindane. Remaining lindane was extracted from the filtrates of fungal liquid cultures (above) and from homogenized fungal liquid cultures (below).

Slika 2. Razgradnja lindana gljivama. Preostali lindan izdvojen je iz filtrata tekuće kulture gljiva (gore) i iz homogenizirane tekuće kulture gljiva (dolje). 

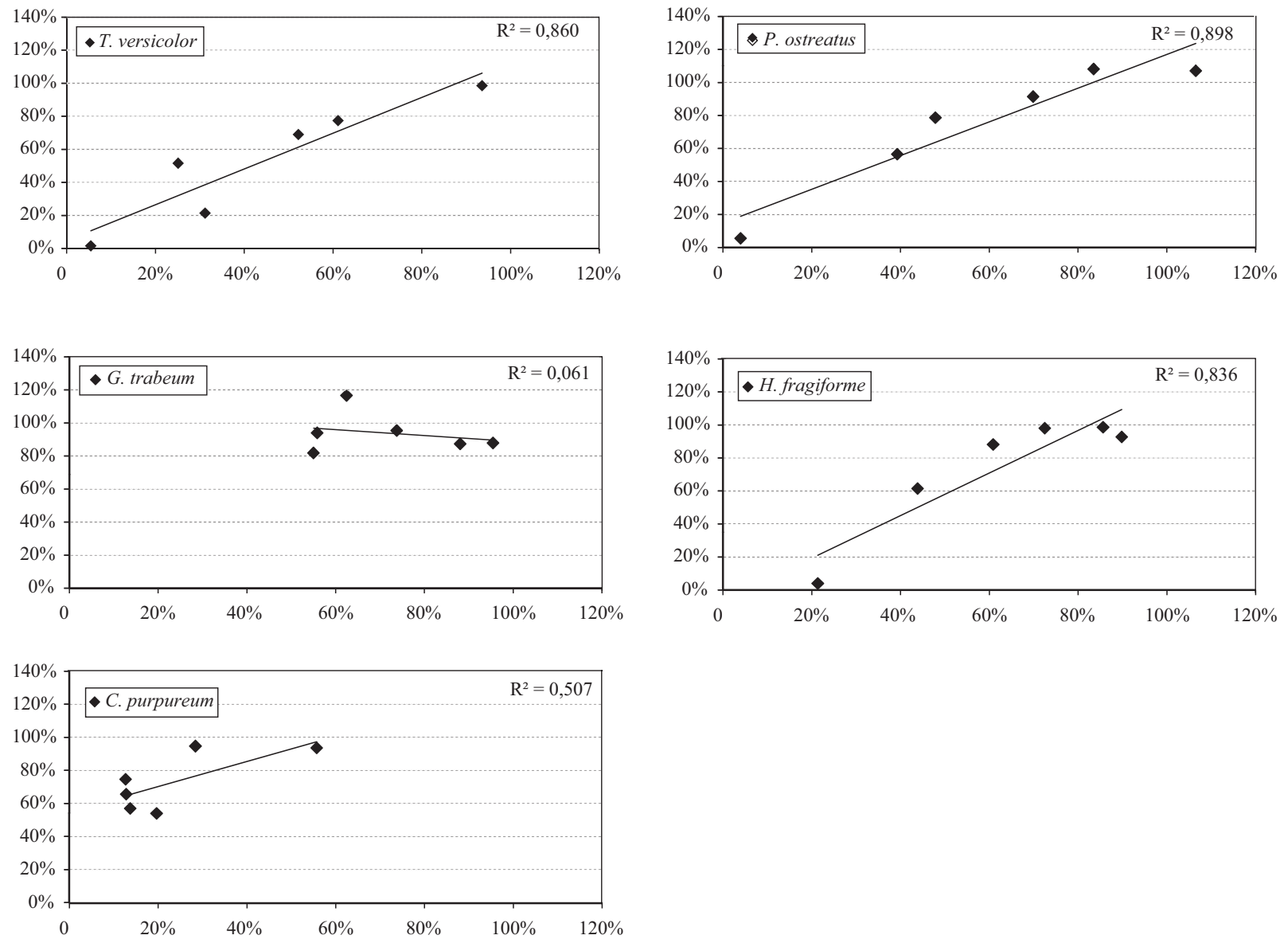

Figure 3 Correlation between extraction methods. The amount of residual lindane obtained with filtration of fungal liquid cultures is plotted on the $\mathrm{x}$-axis and the amount of residual lindane obtained with homogenization of fungal liquid cultures is plotted on the y-axis.

Slika 3. Korelacija među ekstrakcijskim metodama. Količina preostalog lindana dobivena filtracijom tekućih kultura gljiva ucrtana je na $x$-osi, a količina preostalog lindana dobivenog homogenizacijom tekućih kultura gljiva ucrtana je na $y$-osi.

Lindane removal was noticed already after 10 minutes of exposure, regardless of the extraction procedure and the fungal species, except in case of $P$. ostreatus.

After 21 days of exposure in liquid cultures of $T$. versicolor, $98 \%$ of lindane degradation was determined using extraction from homogenized cultures, which was the highest degradation percentage observed (Fig. 2 , below). Comparing the two extraction procedures in terms of degradation rates, no significant difference was observed. The course of lindane degradation with $P$. ostreatus resembled that of $H$. fragiforme. Noticeable degradation started between 6 hours and 1 day of exposure, and both fungi degraded lindane significantly after 3 days. After 21 days, less than $10 \%$ of initial lindane was determined. The extraction procedures did not affect the determination of the remaining lindane, as both methods resulted in similar degradation intensities.

Degradation of lindane with C. purpureum differed greatly from the degradation with all the other fungi in this experiment. It appeared that all degradation of lindane occurred between 6 hours and 1 day of exposure and the amount of degraded lindane did not change substantially with further increase of exposure time.

Brown rot G. trabeum was the least effective in lindane degradation, as expected. The highest removal of lindane was measured after 1 day of exposure, regardless of the extraction method used.

High coefficients of determination $\left(R^{2}\right)$ were observed for $T$. versicolor, $P$. ostreatus and $H$. fragiforme (Fig. 3), indicating a clear correlation between extraction procedures used. Degree of correlation between extraction procedures was significantly lower for C. purpureum and practically no correlation was found when G. trabeum was studied (Fig. 3).

The experiments showed that in comparison to the controls, the addition of lindane did not inhibit the growth of all examined fungi nor affect it in any other way.

\section{DISCUSSION AND CONCLUSIONS 4. RASPRAVA I ZAKLJUČCI}

Comparison of the degradation results using T. versicolor, $H$. fragiforme, and $P$. ostreatus, obtained with the two extraction procedures, indicates that these fungi degraded lindane and that its removal was not due to adsorption onto the fungal biomass. High $R^{2}$ values observed for the linear correlation between residual lindane amounts, which were separately determined in liquid cultures of these fungi with both extraction procedures, further support our findings. In all cases 
similar degradation intensity was observed. However, it can be seen that differences in the amount of residual lindane, obtained with the two extraction methods are more evident in case of fungi, which lack or exhibit lower remediation potential and in samples where shorter exposure periods were examined. This is in accordance with the hypothesis that lindane is removed from the medium also via adsorption onto mycelia, which is a rather quick phenomenon. After longer exposure periods these differences diminished, as lindane was successfully degraded by fungal enzymes over time. During homogenization of the sample, the whole amount of the remaining lindane in the medium was extracted, including the possible adsorbed portion, making this procedure more suitable for the evaluation of degradation of lindane from the liquid medium.

When exposed to a brown rot G. trabeum, low lindane removal was observed, probably all due to adsorption. The same can also be concluded from the respective $\mathrm{R}^{2}$ value, which does not prove any correlation between extraction procedures. This corresponds to the forecasts, since brown-rot fungi lack the ligninolytic enzymes, which degrade lignin and most likely organopollutants as well. Similar results were obtained with C. purpureum, a white-rot fungus, which degraded lindane to a lesser extent than the other white-rot fungi used in this experiment and presumably lindane removal from the culture media occurred by adsorption as well (supported by $R^{2}$ value of 0.5 ). There were major differences in determined degradation intensity of lindane by $C$. purpureum with respect to the extraction procedure used (Fig. 2). In all samples, the amount of extracted remaining lindane was much higher when homogenization was used, indicating that a significant amount of added lindane adsorbed onto the mycelial surface and could not be detected with extraction from filtrates. It can therefore be assumed that $C$. purpureum degraded lindane to a lower extent than the other tested white-rot fungi and that lindane removal from the liquid media occurred not only due to fungal degradation but also as a result of adsorption. Ghosh et al. (2009) reported a very fast rate of adsorption of lindane onto the fungal biomass. This coincides with the results of this study, as the amount of lindane, extracted from the filtrates of the cultures of this fungus, exposed to lindane for only 10 minutes, was already significantly lower than in the controls.

Lindane is capable of adsorption onto various surfaces, e.g. glass and fungal mycelia (Young and Banks, 1998; Nollet, 2007; Ghosh et al., 2009). It was therefore suspected that not the full amount of adsorbed lindane could be extracted when extracting lindane from the filtrates. On the contrary, the whole amount of lindane should be extracted from the homogenized liquid cultures. By comparing the measured degradation rates obtained by respective protocols, it is possible to deduce whether lindane was removed from the media because of degradation by the fungi, adsorption onto fungal biomass, or both. Based on our study it can be concluded that adsorption may be one of the mechanisms for lindane removal from the liquid medium. Fun- gal mycelia, representing extensive potential surface adsorption sites, should therefore also be analyzed for possible adsorption as sole filtered samples taken from the medium are not adequately representative for the degradation analyses.

Interactions between the growth mycelia, fungal enzymes, growth medium, pollutant and its putative metabolites or even growth medium and the pollutant alone contribute to a complex matrix, which makes extraction of organic pollutants difficult, leading to aberrations such as residual lindane exceeding $100 \%$ (Rivero et al., 2012). Homogeneity of fungal liquid cultures, as well as of all other biological systems, is hard to achieve, which together with difficult lindane analytical procedures adds to such deviations.

The chromatograms of the extracts, regardless of the fungal species, contained no additional peaks, which could be correlated to chlorinated degradation metabolites of lindane. Some representative samples were analyzed with gas chromatography coupled to mass spectrometry (data not shown), which also did not confirm any chlorinated products of lindane degradation. Complete absence of any degradation metabolites adds to the obscurity of the degradation mechanism previously described (Mougin et al., 1996; Singh and Kuhad, 1999) and remains the subject of further studies.

\section{Acknowledgements - Zahvala}

This study was supported by Slovenian Research Agency's Junior Researcher Programme Grant 100009-310196.

\section{REFERENCES}

\section{LITERATURA}

1. Aro, N.; Pakula, T.; Penttilä, M., 2005: Transcriptional regulation of plant cell wall degradation by filamentous fungi. FEMS Microbiol. Rev. 29: 719-739 http://dx.doi.org/10.1016/j.femsre.2004.11.006.

2. Bumpus, J. A.; Tien, M.; Wright, D.; Aust, S. D., 1985: Oxidation of persistent environmental pollutants by a white rot fungus. Science (Wash.) 228: 1434-1436 http://dx.doi.org/10.1126/science.3925550.

3. Cullen, D., 1997: Recent advances on the molecular genetics of ligninolytic fungi. J. Biotechnol. 53: 273-289 http://dx.doi.org/10.1016/S0168-1656(97)01684-2.

4. Faison, B. D.; Kirk, T. K., 1985: Factors involved in the regulation of a ligninase activity in Phanerochaete chrysosporium. Appl. Environ. Microbiol. 49: 299-304.

5. Faison, B. D.; Kirk, T. K.; Farrel, R. A., 1986: Role of veratryl alcohol in regulating ligninase activity in Phanerochaete chrysosporium. Appl. Environ. Microbiol. 52: 251-254.

6. Ghosh, S.; Das, S. K.; Guha, A. K.; Sanyal, A. K., 2009: Adsorption behavior of lindane on Rhizopus oryzae biomass: physico-chemical studies. J. Hazard. Mater. 172: 485-490 http://dx.doi.org/10.1016/j.jhazmat.2009.06.156.

7. Hadar, Y.; Cohen-Arazi, E., 1986: Chemical composition of the edible mushroom Pleurotus ostreatus produced by fermentation. Appl. Environ. Microbiol. 51: 1352-1354.

8. Janse, B. J. H.; Gaskell, J.; Akhtar, M.; Cullen, D., 1998: Expression of Phanerochaete chrysosporium genes encoding lignin peroxidases, manganese peroxidases, and 
glyoxal oxidase in wood. Appl. Environ. Microbiol. 64: 3536-3538

9. Kirk, T. K.; Farrell, R. L., 1987: Enzymatic »combustion «: the microbial degradation of lignin. Ann. Rev. Microbiol. 41: 465-505 http://dx.doi.org/10.1146/annurev.mi.41.100187.002341.

10. Lal, L.; Saxena, D. M. 1982: Accumulation, metabolism, and effects of organochlorine insecticides on microorganisms. Microbiol. Rev. 46: 95-127.

11. Moreira, M. T.; Feijoo, G.; Sierra-Alvarez, R.; Lema, J.; Field, J. A., 1997: Biobleaching of oxygen delignified kraft pulp by several white rot fungal strains. J. Biotechnol. 53: 237-251 http://dx.doi.org/10.1016/S0168-1656(97)01676-3.

12. Mougin, C.; Pericaud, C.; Malosse, C.; Laugero, C.; Asther, M., 1996: Biotransformation of the insecticide lindane by the white rot basidiomycete Phanerochaete chrysosporium. Pestic. Sci. 47: 51-59

http://dx.doi.org/10.1002/(SICI)1096-9063(199605) 47:1<51::AID-PS391>3.0.CO;2-V.

13. Muñoz, C.; Guillén, F.; Martínez, A. T.; Martínez, M. J., 1997: Induction and characterization of laccase in the ligninolytics fungus Pleurotus eryngii. Curr. Microbiol. 34: 1-5 http://dx.doi.org/10.1007/s002849900134.

14. Nollet, L. M. L., 2007: Handbook of water analysis. $2^{\text {nd }}$ edition, Boca Raton: CRC Press http://dx.doi.org/10.1201/9781420006315.

15. Quintero, J. C.; Moreira, M. T.; Feijoo, G.; Lema, J. M., 2008: Screening of white rot fungal species for their capacity to degrade lindane and other isomers of hexachlorocyclohexane (HCH). Cien. Inv. Agr. 35: 123-132.

16. Pointing, S. B., 2001: Feasibility of bioremediation by white-rot fungi. Appl. Microbiol. Biotechnol. 57: 20-33 http://dx.doi.org/10.1007/s002530100745.

17. Raspor, P.; Smole-Možina, S.; Podjavoršek, J.; Pohleven, F.; Gogala, N.; Nekrep, F. V.; Rogelj, I.; Hacin, J., 1995: ZIM: zbirka industrijskih mikroorganizmov. Katalog biokultur. Ljubljana: Biotehniška fakulteta, Katedra za biotehnologijo.

18. Rivero, A.; Niell, S.; Cesio, V.; Cerdeiras, M. P.; Heinzen, H., 2012: Analytical methodology for the study of endosulfan bioremediation under controlled conditions with white rot fungi. J. Chromatogr. B 907:168-172 http://dx.doi.org/10.1016/j.jchromb.2012.09.010.

19. Scheel, T.; Höfer, M.; Ludwig, S.; Hölker, U., 2000: Differential expression of manganese peroxidase and laccase in white-rot fungi in the presence of manganese or aromatic compounds. Appl. Microbiol. Biotechnol. 54: 686-691 http://dx.doi.org/10.1007/s002530000427.

20. Singh, B. K.; Kuhad, R. C., 1999: Biodegradation of lindane ( $\gamma$-hexachlorocyclohexane) by the white-rot fungus Trametes hirsutus. Lett. Appl. Microbiol. 28: 238-241 http://dx.doi.org/10.1046/j.1365-2672.1999.00508.x.

21. UNEP, 2009: Report of the Conference of the Parties of the Stockholm Convention on Persistent Organic Pollutants on the Work of its Fourth Meeting. UNEP/POPS/ COP.4/38, vol. 8, May 2009.

22. Willet, K. L.; Ulrich, E. M.; Hites, R. A., 1998: Differential toxicity and environmental fates of hexachlorocyclohexane isomers. Environ. Sci. Technol. 32: 2197-2207 http://dx.doi.org/10.1021/es9708530.

23. Young, E.; Banks, C. J., 1998: The removal of lindane from aqueous solution using a fungal biosorbent: the influence of $\mathrm{pH}$, temperature, biomass concentration and culture age. Environ. Technol. 19: 619-625 http://dx.doi.org/10.1080/09593331908616718.

24. Zucchini-Pascal, N.; de Sousa, G.; Rahmani, R., 2009: Lindane and cell death: at the crossroads between apoptosis, necrosis and autophagy. Toxicology 256: 32-41 http://dx.doi.org/10.1016/j.tox.2008.11.004.

\section{Corresponding address:}

\section{Assistant AJDA ULČNIK}

University of Ljubljana

Biotechnical Faculty

Rožna dolina cesta VIII/34

1000 Ljubljana, SLOVENIA

Tel.: +386 13203640

Fax: +386 14235035

E-mail: ajda.ulcnik@bf.uni-lj.si 